\title{
Social policy on the rural coastal communities: why the implementation fails?
}

\author{
Wayu Eko Yudiatmaja ${ }^{1, *}$, Dwi Kristanti $^{2}$, Imam Yudhi Prastya $^{1}$, Yudithia Yudithia ${ }^{3}$,Tri \\ Samnuzulsari ${ }^{4}$, Suyito Suyito ${ }^{5}$, and Dian Prima Safitri ${ }^{1}$ \\ ${ }^{1}$ Department of Public Administration, Universitas Maritim Raja Ali Haji, Tanjungpinang, Indonesia \\ ${ }^{2}$ Department of Public Administration, Universitas Terbuka, Indonesia \\ ${ }^{3}$ Secretary Office of the Regional House of Representatives of Kepulauan Riau, Indonesia \\ ${ }^{4}$ Department of Sociology, Universitas Maritim Raja Ali Haji, Tanjungpinang, Indonesia \\ ${ }^{5}$ Faculty of Applied Social Sciences, Universiti Sultan Zainal Abidin (UniSZA), Trengganu, Malaysia
}

\begin{abstract}
This paper analyses the failure of social policy implementation for rural coastal communities. We focus on the comparison of two social policies for fishermen communities. This research was carried out in rural coastal areas in Natuna and Bintan, Kepulauan Riau, Indonesia. We used a qualitative approach to explore both the content and the context of the policies. A series of participants were approached through an in-depth interview. This study shows that the stressing on the policy content has ignored the policy context, causing policy failure. Theoretically, this research adds to the body of literature on policy implementation by offering a comparative case study. In the process of implementing public policy, we practically suggest to the government to provide special attention to the context of where the policy is implemented to minimize the policy failure.
\end{abstract}

\section{Introduction}

Indonesia is an archipelagic country with thousands of islands surrounded by $81,000 \mathrm{Km}$ of coastline, 5.8 million $\mathrm{Km}^{2}$ sea area, and 2.78 million $\mathrm{Km}^{2}$ exclusive economic zones. Indonesia also has a number of marine resources with a thousand fishermen, depending on the marine sector. Potentially, Indonesia's fisheries are the largest in the world, both capture fisheries and aquaculture. Based on the modes of production, fisheries are divided into two categories, namely capture and aquaculture fisheries, with an annual sustainable production of fisheries, around 67 million tons a year. From this number, the potential for sustainable production of marine capture fisheries is 9.3 million tons per year, and capture fisheries of inland areas (lakes, rivers, reservoirs, and swamps) amount to 0.9 million tons making total capture fisheries 10.2 million tons per year. The remaining 56.8 million tons/year is aquaculture, both marine cultivation, brackish aquaculture (ponds), and freshwater cultivation (land) [1]. In 2016, Indonesian fish production was around 185.2 tons of fish, with IDR 3.1 million of production value [2] generated by approximately 1.6 million fishermen.

\footnotetext{
* Corresponding author: wayuguci@umrah.ac.id
} 
Although Indonesia has extensive sea resources, it has not in line with the wealth of Indonesian fishermen. The condition of Indonesian fishers is still worrying in order to put them as a vulnerable group in the social structure. As a consequence, they are often referred to as the poorest of the community groups. They are currently related to the poorest of the poor because of structural, natural, and cultural constraints. Based on World Bank data, there are 25.91 million people or 20.62 percent of the total population of Indonesia in 2018 are poor and vulnerable to poverty [3]. The Central Bureau of Statistics (BPS), with a different calculation from the World Bank, announced that the poverty rate in Indonesia was 26.42 million people (9.78 percent) in March 2020 [4]. Surprisingly, much of the poor are in rural and coastal areas. The 2017 National Socio-Economic Survey (SUSENAS) data shows fishermen as one of Indonesia's vulnerable professions. As many as $11.34 \%$ of people in the fisheries sector are classified as poor, higher than the restaurant service sector $(5.56 \%)$, building construction $(9.86 \%)$, and waste management $(9.62 \%)$ [5].To enhance the quality of life of Indonesian fishermen, the government formulates a variety of social policies. It has been regulated in Act No. 32 of 2014 about marine. Social assistance refers to the provision of aid in the form of money or goods from local governments to individuals, groups, families, or communities of fishermen [6]. It is implemented to avoid possible social risks and problems, such as poverty, unemployment, and isolation for fishermen households. Furthermore, social protection for fishermen is led by inequality among fishery resource users, so fishers and fish breeders need more protection differentiating them from other users.

The diversity of studies has explained the effect of social policy on the community. Unfortunately, we still lack understanding of the case in the context of rural coastal communities because most of the study is conducted in rural agricultural communities [7]. Therefore, we address the gap in the current study by focusing on the rural coastal community. In the present study, we focused on comparative analysis of social assistance provided by the government to rural coastal communities in Kepulauan Riau. In the first case, we seek social policy on the fishermen in Natuna. Subsequently, we shed light on the case of social assistance for the fishermen in Bintan. This study aims to illuminate the process of social policies and the effect of social policies on the community's circumstances.

\section{Methods}

This is a qualitative case study research to achieve the objectives of the investigation. Specifically, this research aims to compare two circumstances, fishermen in Natuna Regency and Bintan Municipality, Kepulauan Riau. The case study research was an examination and review of a single or collective event, aimed at capturing the meaning of the study object [8]. We used the case study because it can capture the circumstances of social policies obviously by comparing two cases.

We approached the subjects of this research using non-participant observation. Data were collected using interviews on the fishermen, Marine and Fisheries Office, community's figure, cooperatives of fishermen, and households in two case study sites, the Natuna and Bintan rural coastal communities. The qualitative interviews were conducted to obtain an understanding of the subjective meanings applied by individuals regarding the implementation of several social policies in two research settings. Furthermore, it was employed to explore the issue of what and how the implementation fails. We approached the participants by using an interview guide prepared before. The questions invoked were related to the forms, response, attitude, and the problem of social assistance provided to a rural coastal community in Kepulauan Riau.

Data were processed using thematic analysis by comparing the case of Natuna and Bintan. Thematic analysis is a way to analyse data to identify patterns or find themes through the data collected by the researcher [9]. This method was chosen because it is very useful in 
analysing in detail qualitative data. It can help find related patterns in the phenomenon and explain the extent to which a phenomenon occurs through the researcher's lens. In this research, the process of thematic analysis was relied on four stages, involving understanding the data, compelling the code, finding a theme, and concluding [10].

\section{Results and Discussion}

\subsection{Findings}

\subsubsection{Natuna Case}

The Ministry of Marine and Fisheries had given several assistance to the fishermen cooperatives in Natuna Regency, Kepulauan Riau, in early 2018. It is provided to help the fishermen to improve their fish capture. It included fiber ships, a global position system (GPS), and a wire-fish trap. In addition, the government also delivered a cash transfer program to the fisherman's household. The government routinely offers IDR 600,000 - per three months to the family. The types and functions of each social relief are illustrations in Table 1 and Figure 1.

Table 1. Social policies for Natun fishermen

\begin{tabular}{|l|l|l|}
\hline \multicolumn{1}{|c|}{ Type } & \multicolumn{1}{c|}{ Use } & \multicolumn{1}{c|}{ Recipient } \\
\hline Fiber ship & $\begin{array}{l}\text { As transportation to catch the } \\
\text { fish }\end{array}$ & A group of fishermen \\
\hline Global position system (GPS) & To tag the ship's location & A group of fishermen \\
\hline Fishfinder & $\begin{array}{l}\text { To detect the potential } \\
\text { location of fish }\end{array}$ & A group of fishermen \\
\hline Wired-fish trap & To catch a fish & A group of fishermen \\
\hline Cash transfer & $\begin{array}{l}\text { To enhance the purchasing } \\
\text { power of households }\end{array}$ & Individual \\
\hline
\end{tabular}

Source: Data processed (2020)

Firstly, the government provided 60 fiber ships to the fishermen cooperatives. The ships are classified into three types, including five, ten, and thirty gross tons. The fiber ship was delivered to the fishermen as permanent sea transportation to replace traditional wooden ships of the fishermen. Afterward, the global position system (GPS) to the fishermen is likewise provided to identify the location of the vessel. By using GPS, the fishermen can save on operational costs because it can find the coordinates of latitude, longitude, direction, and speed. GPS is beneficial for fishermen to find out their position at sea to determine travel routes, mark necessary places, such as places with plentiful fish, shipwrecks, shallows, and so on. It can also assist in determining the direction of the wind. If it rains and cloudy, GPS can show the direction of the wind to ensure their position in the sea. Apart from GPS, fishermen are also completed with a fish finder or often referred to as coral radar. A fish finder is a necessary tool to precisely find the fish. It consists of a display in the form of a monitor transducer needed to go to the sea. The transducer can scan the presence of fish in the sea, and the results will be displayed on the screen. Using fish finder, fishers can find out information about the fish, underwater topography, and sea depth. It helps the fishermen to find fish easier in order to increase their fish catch. Lastly, the government provides a wiredfish trap to catch the fish. 


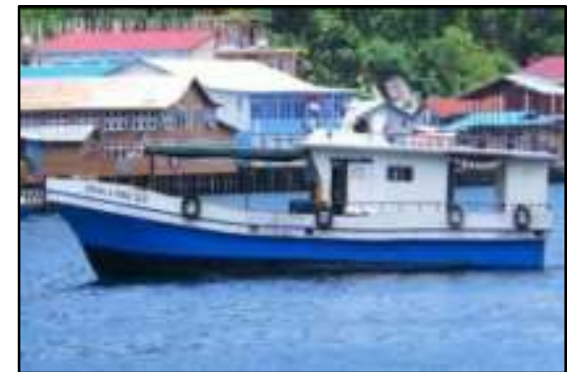

The fiber ship

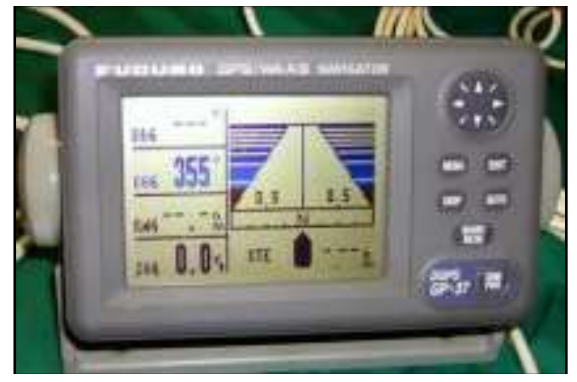

The global position system (GPS)

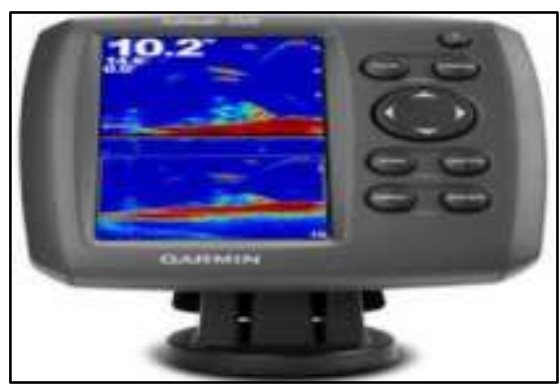

Fishfinder

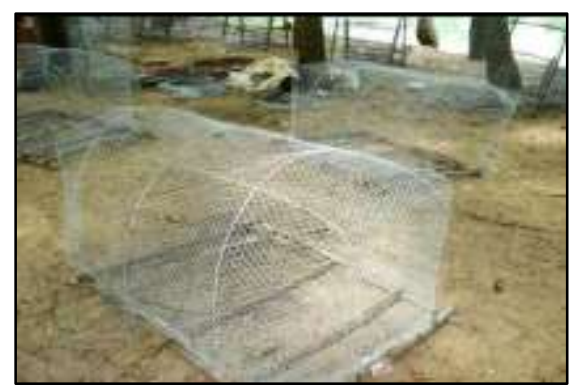

The wired-fish trap

Fig. 1. The assistance for Natuna's fishermen

Although the reliefs are worthwhile, it fails to achieve the goals to increase the fishermen's economic well-being. Three crucial issues dealt with implementing these programmes: time delay, inappropriate, hard to use, and control. First, the aids provided frequently come too late. The slow pace of assistance commonly makes people disappointed because what they expected has not been provided. The fishermen have to wait extensive enough to obtain what the government promised. There are even fishermen who do not gain these supports. Consequently, the community switches to other jobs, not their expertise, such as motorcycle taxi drivers, small merchants, and farmers. Second, the government's assistance does not match the community's needs, such as fiber ship, whose weight is too large so that fishermen are overwhelmed in caring for them and extravagant fuel. Rather than being used and wasted, most of the boat is sold by the fishermen. Third, many fishers could not operate GPS, fishfinder, and fishing gear provided by the government because there was no training before the equipment was distributed.

\subsubsection{Bintan Case}

In 2010, the construction of desalination infrastructure in the Dendun Village, Mantang Subdistrict, Bintan Municipality, Kepulauan Riau was implemented by the Ministry of Public Works. This project is called seawater distillation; the seawater reverse osmosis (SWRO) desalination method uses RO (reverse osmosis) membrane to probe dissolved salt content to obtain pure water. The SWRO method was chosen because it was considered more effective. Moreover, the project was possible to implement based on the geographical conditions of Dendun. SWRO is a way to take advantage of the abundant amount of seawater as well as a solution to overcome the shortage of clean water. The program is expected to impact increasing the income of villagers, both directly and indirectly. Because the price for buying 
clean water is relatively high, this programme's implementation can reduce public expenditure and increase community welfare.

The cost required to operate the SWRO, for five hours of operation per day, the cost of chemical drugs to manage saltwater to become fresh is IDR 30 million to IDR40 million per month. Meanwhile, electricity costs around IDR 90 million to IDR 100 million per month. Maintenance costs cannot be budgeted temporarily because of the budget constraints of the Bintan Government. Therefore, the maintenance fee will be charged to the community through the service cost. Two rates will be applied to customers-namely, non-subsidized household rates and subsidized rates. The non-subsidized tariff is IDR 25,760 per cubic, and the subsidized price is IDR 15,500 per cubic.

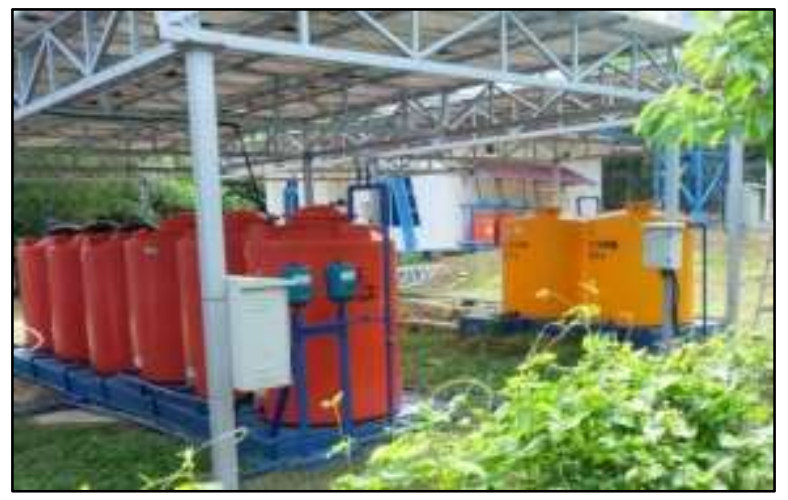

Fig. 2. SWRO Facility in Bintan

In the development, the implementation of SWRO in the Bintan rural coastal community faces numerous problems. First, the programme was solely determined by the government without involving society as a target group. SWRO is not entirely following the needs and desires of the Dendun community because the community needs more clean water to meet their daily needs or domestic household needs, such as washing, bathing, and others. Meanwhile, the SWRO provided by the government is utilized to produce fresh water ready to drink. Second, SWRO needs a big budget for mechanical maintenance, and it is charged to the community. On the other side, the community has not been the ability to maintain the machine. Many of the people in Dendun are lacking, so they cannot pay the maintenance fee of SWRO.

\subsection{Discussion}

The results show that the government only focused on the policy content or policy forms and ignores the context of policy. Policy context is associated with the socio-cultural environment and accepting the recipient's capacity on the policy [11]. The findings of this study confirm the theory of implementation studies stressing both policy content and policy context [12], especially the context of Indonesian rural coastal communities [13], [14]. Our results also in line with previous studies explaining social policy for the rural community [15]-[17]. For instance, Teh et al. examine the effect of fishery buyback policy on fishermen's socioeconomic conditions in Australia, the U.S., Canada, and Norway. They found that social enterprises are deeply rooted in their local places and local societies, despite variations in scale, structure, purpose, and age. The assessed buybacks were a massive success because of latent permits or permits, effort creep, and ongoing fishery reinvestment. A strong economy, accountable leadership, and social assistance programs tailored to local fishing communities have been enabling conditions for positive social outcomes. Our study also provides an 
essential recommendation to the government to consider several rural coastal communities' contextual factors in delivering social policy.

\section{Conclusion}

This study examines the social policies for fishermen in rural coastal areas and what factors affect the policy implementation's failure. Drawing on the cases of social policies in Kepulauan Riau, our findings clearly point out that the neglect of policy context has rendered policy failure. Because of focusing on policy contents, the government ignores that social policy is delivered to rural coastal communities who have several limitations in receiving the assistance. As a result, the policies fail to attain the goals. This research reinforces the study of contextual-based policy implementation by furnishing the case of social policy in the context of rural coastal communities in Indonesia. These results also contribute to implementing the government's social policy to give special attention to the community's socio-cultural context in rural coastal areas.

Acknowledgements. The authors are indebted to the committee of the International Conference on Agribusiness and Rural Development (IconARD) 2020, who has facilitated our paper to be presented and published at the conference's proceeding. The authors also thank an anonymous reviewer for the valuable comments on the manuscript.

\section{References}

1. Potensi Perikanan Indonesia | Dewan Pertimbangan Presiden (Wantimpres). [Online]. Available: http://wantimpres.go.id/?p=1388\&lang=id. [Accessed: 24-Aug-2020].

2. Badan Pusat Statistik, Statistik produksi perikanan yang didaratkan di pangkalan pendaratan ikan 2016 (Badan Pusat Statistik, Jakarta, 2016)

3. Ikhtisar. [Online]. Available: https://www.worldbank.org/in/country/indonesia/overview. [Accessed: 24-Aug-2020].

4. Badan Pusat $\quad$ Statistik. [Online]. Available: https://www.bps.go.id/pressrelease/2020/07/15/1744/persentase-penduduk-miskinmaret-2020-naik-menjadi-9-78-persen.html. [Accessed: 24-Aug-2020].

5. Z. Anna, A. A. Yusuf, A. S. Alisjahbana, A. A. Ghina, R. Rahma, Mar. Policy 106 (2019)

6. W. E. Yudiatmaja, Implementasi dan evaluasi kebijakan publik (UMRAH Press, Tanjungpinang, 2016)

7. M. Pawar, Int. J. Community Soc. Dev. 1, 1 (2019)

8. J. W. Creswell, Research design: Qualitative, quantitative, and mixed methods approaches (Sage, Los Angeles, 2013).

9. A. Castleberry and A. Nolen, Curr. Pharm. Teach. Learn. 10, 6 (2018)

10. M. J. Belotto, Qual.Rep. 23, 11 (2018)

11. W. E. Yudiatmaja, T. Samnuzulsari, S. Suyito, Y. Yudithia, IOP Conf. Ser. Earth Environ. Sci. 423, 1 (2020)

12. M. S. Grindle, Policy content and context in implementation, in Politics and policy implementation in the third world, M. S. Grindle, Ed. (Princeton University Press, New Jersey, 2017)

13. W. E. Yudiatmaja, Y. Yudithia, T. Samnuzulsari, S. Suyito, E. Edison, IOP Conf. Ser. Mater. Sci. Eng. 771, 1 (2020)

14. W. E. Yudiatmaja, Y. Yudithia, T. Samnuzulsari, S. Suyito, IOP Conf. Ser. Earth Environ. Sci. 423, 1 (2020) 
15. A. Bennett, A. Ravikumar, P. Cronkleton, Land Use Policy 70 (2018)

16. L. S. L. Teh, N. Hotte, U. R. Sumaila, Marit. Stud. 16, 1 (2017)

17. X. Zhang and K. M. Bartol, Empowerment and employee creativity: A cross-level integrative model, in The Oxford handbook of creativity, innovation, and entrepreneurship (Oxford University Press, Oxford, 2015) 